\title{
Towards a New
}

Audiovisual

Think Tank

for Audiovisual

Archivists and

Cultural Heritage

Professionals

Peter B. Kaufman

Intelligent Television and MIT

January 2018 


\section{About this White Paper}

Towards a New Audiovisual Think Tank for Audiovisual Archivists and Cultural Heritage Professionals is published by the Netherlands Institute for Sound and Vision. Sound and Vision is the Dutch national institute for media and culture. Through its holdings of over a million hours of material, its expertise, and activities, Sound and Vision aims to strengthen an open and free society. Today, it offers its holdings to the broadest variety of end-users, including journalists, students, researchers, heritage organisations, and the general public.

Sound and Vision is assembling a new Audiovisual Think Tank that brings together visionary experts in the AV cultural heritage sector to map out our shared strategic priorities over the next ten years. Through this Think Tank, Sound and Vision aims to lay the groundwork for an AV archiving sector that enables more long-term use, learning, and education.

To download this White Paper or learn more about the new AV Think Tank, please visit: www.beeldengeluid.nl/avthinktank or contact avthinktank@beeldengeluid.nl.

\section{About the Author}

Peter B. Kaufman is a writer, teacher, and documentary film producer. He is president of Intelligent Television, where he executive produces Intelligent Television's media productions and directs the company's research and strategic consulting work. He has served as co-chair of the JISC Film \& Sound Think Tank in the United Kingdom and co-chair of the Copyright Committee of the Association of Moving Image Archivists. He also served as Associate Director of Columbia University's Center for Teaching and Learning for several years and is currently Research Affiliate at the Office of Digital Learning at MIT. His forthcoming books include The New Enlightenment: The Promise of Film and Sound in the Digital Age (Seven Stories Press) and The Columbia Manual of Video Style: A Guide to the Use of Video in Scholarly Publishing (Columbia University Press). He thanks the William and Flora Hewlett Foundation and MIT for their support of his work and Aubéry Escande, John Koch, Rachel Somers Miles, and Jeff Ubois for their sound and visionary advice.

Sound and Vision circulated earlier drafts of this paper for comments to senior archival and production specialists and among leaders of cultural and educational institutions participating in the 2017 FIAT/IFTA World Conference in Mexico City. Tony Ageh, Lora Aroyo, Emma Beer, Jean-Hugues Chenot, Paul Gerhardt, Roger MacDonald, Johan Oomen, Lai Tee Phang, Richard Ranft, Pelle Snickars, Daniel Teruggi, Bill Thompson, William Uricchio, Erwin Verbruggen, and Richard Wright all contributed substantially to this work with their readings and comments; their suggestions are appreciated here with deep gratitude.

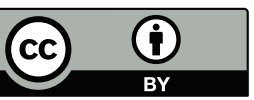

Copyright @ Intelligent Television, Inc., 2018. All original writing, text, and ideas herein may be reused and published/republished freely by anyone for any purpose, subject to the terms in the Creative Commons Attribution 4.0 International License (https://creativecommons.org/licenses/by/4.0/legalcode).

Cite as: Peter B. Kaufman, Towards a New Audiovisual Think Tank for Audiovisual Archivists and Cultural Heritage Professionals (Hilversum, NL: Netherlands Institute for Sound and Vision, 2018).

DOI: http://dx.doi.org/10.18146/2018thinktank01 


\section{From Sound and Vision}

This White Paper is being published by the Netherlands Institute for Sound and Vision as part of a new initiative to facilitate stakeholders large and small in the preservation of audiovisual heritage to take collective action in our fast-moving and increasingly strange world - a world where concerted efforts to preserve and share our information and knowledge are now more important than ever. This White Paper is one of the first steps that Sound and Vision is taking to establish a new international thought leadership group, a community of forward-looking thought leaders who will articulate an international research and action agenda - and certain funding priorities - for the audiovisual cultural heritage sector, broadly defined, over the next 10 years. 



\section{Introduction}

Perhaps this White Paper should begin with a general recognition that the common task of audiovisual archivists - of cultural heritage archivists in general - has often been characterized as essentially a ... defensive vocation. "[M]ost of world's twentieth century audiovisual heritage is at risk of being lost," as the challenge is usually defined - and so, in some kind of response, the archivists go to work. 'Archivists' work is seen as the job of rescue, of repair, often with equipment including gloves and masks and special types of glue, much as carpenters might try to attend to the repair needs of aging wooden churches, or specialized masons to crumbling monuments. ${ }^{2}$

Audiovisual archivists do indeed wage their battles and run their races against time (oddly enough, with time-based media ${ }^{3}$ ), and they minister to all the needy and afflicted media one can find and imagine - in film archives and in broadcast archives, some days with nitrate film reels of a century ago, some days with hard drives full of born-digital films, which, newness notwithstanding, may face even more accelerated technical and physical obsolescence - or, perhaps more accurately, "degralescence," a new term in our field that blends the twin challenges of media degradation and media and media-player obsolescence. ${ }^{4}$

But archivists' work is hardly defensive. The act of archiving in fact is part of the whole human effort to remember - to know ourselves: the main Delphic nosce te ipsum maxim and something that, it has been remarked, is made even more urgent in the digital age. ${ }^{5} \mathrm{It}^{\prime} \mathrm{s}$ an exploration of the past - but also the future of the past; it's like exploring deep space while we explore the ocean. Archivists bring us on a voyage, or a tour - through inquiry, interrogation, curation, and analysis - almost always with a bit of production, and almost always with a bit of the new. ${ }^{6}$ Archiving, properly defined, is the establishment and then

\footnotetext{
1 "Sound and Image Collections Conservation (SOIMA)," International Centre for the Study of the Preservation and Restoration of Cultural Property, online at: http://www.iccrom.org/priority-areas/soima/.
}

2 http://www.un.org/en/events/audiovisualday/; http://archivesatrisk.com/the-threat/; and http://archivesatrisk.com/ risk_project/the-threat/.

3 The Russian filmmaker Andrei Tarkovsky spoke of time - rather than film, rather than images or words or sounds - as his medium. Tarkovsky, Sculpting in Time: Reflections on the Cinema (Austin: University of Texas Press, 1989).

4 Mike Casey, "Why Media Preservation Can't Wait: The Gathering Storm," IASA Journal 44 (January 2015) online at: https:// www.iasa-web.org/iasa-journal-no-44-january-2015.

5 Marty Perlmutter, "The Lost Picture Show: Hollywood Archivists Can't Outpace Obsolescence," IEEE Spectrum, April 28, 2017, online at: http://spectrum.ieee.org/computing/it/the-lost-picture-show-hollywood-archivists-cant-outpace-obsolescence.

6 Nobel laureate Bob Dylan once wrote, "He not busy being born is busy dying," https://en.wikipedia.org/wiki/It\%27s Alright, Ma (I\%27m_Only_Bleeding). Lifecycle tradeoffs are endlessly debated. "I've seen it argued that an obsession with film preservation is unhealthy, that our energy is better spent on seeking out and funding new talent," says one writer. "Aside from the obvious problem with that idea - film love is not and should never be a zero-sum game between Old and New - this also assumes there is little left to be found on a voyage into the past, as if we've identified the greats and can safely move on." Farran Smith Nehme, "Tonka of the Gallows (1930)," Film Comment, April 19, 2017, online at: https://www.filmcomment.com/blog/tonka-of-the-gallows/. 
stewardship of the human record, and the remembering that it facilitates may be the most critically important imperative in modern human society. ${ }^{7}$ In fact, the current and future significance of audiovisual archive work knows no boundary. ${ }^{8}$

Archiving thus is conducted not only on the back half, the defensive zone, of the field or pitch, as it were; it is also vitally proactive: it's productive publishing. It's not preserving alone, but also capturing and creating the human record - especially when activist groups are involved - and taking forward-facing steps to fulfill these urgent and giant social mandates and imperatives to remember, for today and for tomorrow. ${ }^{9}$ And archives that recognize themselves as media producers, too, in their preservation and access roles - at one point, the Library of Congress predicted that its Packard Campus would be producing 5-plus million gigabytes of digital information every year - often have an easier time of articulating their mission publicly in the digital age. ${ }^{10}$

Thus the important ties between preservation and loss prevention notwithstanding, and all this defensive and rescue work notwithstanding, this White Paper is an affirmative call to action to a progressive group. Our group of course has many members - and a rich diversity of institutional missions, funding levels, reach, ambitions, and competences. We share, though, and most fervently, perhaps, a commitment to preserve and render accessible the assets we curate and

\footnotetext{
7 The Hebrew verb zakhor appears in the imperative - Remember! - in the Bible more often than any other command. Yosef Hayim Yerushalmi, Zakhor: Jewish History and Jewish Memory (Seattle: University of Washington Press, 1982). See also: http://biblehub.com/hebrew/2142.htm.
}

8 Archivists preserved the court recordings of Nelson Mandela and his colleagues, for one example. See: http://fiatifta. org/index.php/save-your-archive/cases/saving-mandela-and-anc-leaders-court-trial-recordings/. Focus on the economic opportunity cost of doing nothing to preserve deteriorating assets like these has been tightly sharpened by the consulting firm AVPreserve with its excellent "Cost of Inaction Calculator" - https://coi.avpreserve.com/ - but the societal costs of inaction remain to be imagined (and toted up). Václav Havel tried, speaking of a loss that is "infinitely deeper and more significant than might appear from the numbers involved." He wrote about a more formal form of destruction: "The forcible liquidation of [. . . ] a journal - a theoretical review concerned with the theatre, say - is not just an impoverishment of its particular readers. It is not even merely a severe blow to theatrical culture. It is simultaneously, and above all, the liquidation of a particular organ of society's self-awareness and, hence, an interference, hard to describe in exact terms, in the complex system of circulation, exchange and conversion of nutrients that maintain life in that many-layered organism which is society today; a blow against the natural dynamic of the processes going on within that organism; a disturbance of the balanced interplay of all its various functions, an interplay reflecting the level of complexity reached by society's anatomy. And just as a chronic deficiency of a given vitamin (amounting in quantitative terms only to a negligible fraction of the human diet) can make a man ill, so, in the long run, the loss of a single periodical can cause the social organism much more damage than would appear at first sight." See Havel's inspirational "Letter to Dr. Gustáv Husák, General Secretary of the Czechoslovak Communist Party," in Havel, Living in Truth: Twenty-Two Essays Published on the Occasion of the Award of the Erasmus Prize to Vaclav Havel, edited by Jan Vladislav (Amsterdam: Meulenhoff, 1986), and quoted at greater length in Peter B. Kaufman, "Two Prague Publishers," Scholarly Publishing 22, no. 3 (April 1991). Vladislav's edited collection, sad to say, is not yet available online in full form - neither at the Internet Archive (https://archive.org/details/ vaclavhavellivin00have) nor in the HathiTrust Digital Library (https://catalog.hathitrust.org/Record/002471389).

9 https://www.youtube.com/watch?v=vUWLqeEf91s\&feature=youtu.be; https://library.witness.org/product/filmingimmigration-and-customs-officials-ice/; and https://library.witness.org/product-category/guide/.

10 Mike Mashon, "The Library of Congress National Audio-Visual Conservation Center," Cinema Journal 46, no. 3 (Spring 2007): 141. As of early 2017, in actuality, there are 7 petabytes of digital content in the Library of Congress archive, with 1.1 petabytes added in 2016 alone. Mike Mashon, correspondence with the author, May 26, 2017. 
steward, and thus we share in the hunt for funding and other resources to digitize and process and catalog all we hold and keep receiving. Perhaps we also, as a collective, recognize that audiovisual archivists and cultural and educational organizations in this forward-facing field need to:

Properly quantify the importance - primacy, even - of audiovisual communication in the modern age - essential to the relevance argument and the funding argument for those who work with audiovisual material. How is it ever lost on anyone that audiovisual communication is the dominant form of media today - and that the audiovisual archive lies at its heart?"1

Fully appreciate the extraordinary intrinsic value - denominated in dollars, on the one hand, and these other cultural and economic benchmarks, on the other - of all our assets, and to consider basing certain of our funding appeals to the world on our roles at the heart, really, of a trillion-dollar industry. ${ }^{12}$

Render the audiovisual materials held in these archives as useful and ubiquitous to the world as text is today - and in this sense, then, recognize our stakes in the growth of the future of the web, the improvement of search, and the expansion of media literacy. Critical to this effort, for archives large and small, is continued digitization for preservation and for access (the "praccess" axis?) to render our cultural record permanent and discoverable and quotable. Critical, too, is militating for broader use rights: the richest possible range of utilities for materials in copyright, out of copyright, and everywhere in between. ${ }^{13}$

Commit to protecting and keeping freedom and human rights - especially freedom of speech expanding in the modern era. The United Nations Universal Declaration on Human Rights, a touchstone charter for human freedom, set forth in 1948 that "everyone has the right to freedom of opinion and expression; this right includes freedom to hold opinions without

11 "Globally [. . . ],video traffic will be 82 percent of all consumer Internet traffic by 2021, up from 73 percent in 2016. ." “Cisco Visual Networking Index: Forecast and Methodology, 2016-2021," online at: http://www.cisco.com/c/en/us/solutions/ collateral/service-provider/visual-networking-index-vni/complete-white-paper-c11-481360.html. A decade after Google bought it in 2006, YouTube alone has more than 1 billion viewers watching hundreds of millions videos every day. https:// www.youtube.com/yt/press/statistics.html; and Mike Isaac, "Facebook Ad Revenue Nearly Triples on Mobile Ad Sales and New Users, The New York Times, July 27, 2016, online at: http://www.nytimes.com/2016/07/28/technology/facebookearnings-mobile-ad-revenue.html.

12 Peter B. Kaufman, Assessing the Audiovisual Archive Market: Models and Approaches for Audiovisual Content Exploitation (Hilversum: Prestocentre, 2012), online at: https://www.prestocentre.org/files/library/resource/assessing the audiovisual archive market.pdf.

13 Paul Gerhardt and Peter B. Kaufman, "Fluency in Film and Sound: A New Cultural Imperative" (London: JISC, 2011), online at: https://sca.jiscinvolve.org/wp/files/2010/07/SCA_DCQuarterly_03_FSTT_Supp-interactive.pdf; "Audiovisual Citation: BUFVC Guidelines for Referencing Moving Image and Sound" (London: British Universities Film and Video Council, 2013), online at: http://bufvc.ac.uk/wp-content/media/2013/03/BUFVC-AV-Citation-ONLINE.pdf; Sian Barber, Using Film as a Source (Manchester: Manchester University Press, 2015); The MLA Handbook (8 ${ }^{\text {th }}$ edition) (New York: Modern Library Association, 2016); and Peter B. Kaufman, The Columbia Manual of Video Style: A Guide to the Use of Video in Scholarly Publishing (New York: Columbia University Press, forthcoming. See also: Ben Moskowitz, "Overhauling One High School Subject Is Our Best Hope for the Future of Democracy," Quartz, January 23, 2017, online at: https://qz.com/887177/overhauling-one-high-school-subject-is-our-best-hope-for-the-future-ofdemocracy/; and Farhad Manjoo, “Can Facebook Fix Its Own Worst Bug?” New York Times Magazine, April 25, 2017, online at: https://www.nytimes.com/2017/04/25/magazine/can-facebook-fix-its-own-worst-bug.html. See also: http:// mediathread.info/content/about-mediathread and https://github.com/ccnmtl/mediathread. 
interference and to seek, receive and impart information and ideas through any media and regardless of frontiers."14 UNESCO's mandate to "promote the free flow of ideas by word and image" followed. ${ }^{15}$ The United Nations (through the UN Human Rights Council) passed a resolution affirming "that the same rights that people have offline must also be protected online, in particular freedom of expression, which is applicable regardless of frontiers and through any media of one's choice, ${ }^{\prime \prime 16}$ and condemning "unequivocally measures to intentionally prevent or disrupt access to or dissemination of information online."17

Keep building the great Enlightenment project - the establishment of a digitized resource of all the world's knowledge, one eventually able to provide knowledge and information and education to everyone on the planet today and forever. ${ }^{18}$

14 The Universal Declaration of Human Rights is online at: http://www.un.org/en/universal-declaration-human-rights/.

15 "Fostering Freedom of Expression," UNESCO, https://en.unesco.org/themes/fostering-freedom-expression; and "About Us," UNESCO, http://www.unesco.org/new/en/communication-and-information/about-us/.

16 “U.N. Human Rights Council: First Resolution on Internet Free Speech," Library of Congress, http://www.loc.gov/law/ foreign-news/article/u-n-human-rights-council-first-resolution-on-internet-free-speech/; and Somini Sengupta, “U.N. Affirms Internet Freedom as a Basic Right," The New York Times, July 6, 2012, https://bits.blogs.nytimes.com/2012/07/06/ so-the-united-nations-affirms-internet-freedom-as-a-basic-right-now-what/.

17 "The Special Rapporteur's 2017 report to the United Nations Human Rights Council is now online," United Nations Human Rights Office of the High Commissioner, http://www.ohchr.org/EN/Issues/FreedomOpinion/Pages/SR2017ReporttoHRC.aspx; and "UNHRC: Reject attempts to weaken resolution on Human Rights and the Internet," Article 19, June 30, 2016, https:// www.article19.org/resources.php/resource/38428/en/unhrc:-reject-attempts-to-weaken-resolution-on-human-rights-and-theinternet. See also: https://da2i.ifla.org/. These multilateral initiatives did not take place in a vacuum. See Karl R. Popper, The Open Society and Its Enemies (Princeton: Princeton University Press, 1966); Miklós Haraszti, The Velvet Prison: Artists under State Socialism (New York: Basic Books, 1987); Václav Havel, Living in Truth (London: Faber and Faber, 1987); and Czeslaw Milosz, The Captive Mind (New York: Vintage Books, 1981). All of these writings are essential reminders of the significance of archiving for humanity. (István Rev, the Hungarian librarian and archivist, reminds us that Socrates said that "seeking and learning are in fact nothing but recollection." Quoted in Rev, Retroactive Justice: Prehistory of Post-Communism [Stanford: Stanford University Press, 2005], 329.) The battles over the future of the audiovisual past in this part of the world were real. The only real bloodshed during the so-called velvet or bloodless revolutions in Central and Eastern Europe during the collapse of communist totalitarianism flowed from fatalities at the foot of television towers in Romania and Lithuania - and later Russia.

18 Peter B. Kaufman, "The New Enlightenment: Film, Sound, and the Promise of New Technology," keynote presentation at PrestoCentre's “Screening the Future” inaugural conference, March 14, 2011, online at: https://www.prestocentre.org/ node/1633\#4 and https://www.slideshare.net/PrestoCentre/towards-a-new-enlightenment-moving-images-recordedsound-and-the-promise-of-new-technology; and Kaufman, The New Enlightenment: The Promise of Film and Sound in the Digital Age (New York: Seven Stories Press, forthcoming). See also: Ray Kurzweil, The Singularity Is Near (New York: Viking, 2005); Nicholas Carr, "The Library of Utopia," MIT Technology Review, April 25, 2012, online at: https://www. technologyreview.com/s/427628/the-library-of-utopia/; James Somers, "Torching the Modern-Day Library of Alexandria," The Atlantic, April 20, 2017, online at: https://www.theatlantic.com/technology/archive/2017/04/the-tragedy-of-googlebooks/523320/; and H. G. Wells, "The Idea of a World Encyclopedia," Harper's Magazine (April 1937), online at: https:// harpers.org/archive/1937/04/the-idea-of-a-world-encyclopedia/. See also: http://gutenberg.net.au/ebooks13/1303731h. html\#ch3. The Ptolemaic kings, with the library/museum of Alexandria, deserve original credit, perhaps. See the discussion of the Library of Alexandria and Google and Wikipedia mission statements in Peter B. Kaufman, MOOCs and Open Educational Resources: A Handbook for Educators (New York and Lakeville, CT: Intelligent Television, 2016), online at: http://www.intelligenttelevision.com/research/entry/redefining-open. 
Throughout, this White Paper is animated by two overarching beliefs. The first is that the value of the work that we do will grow only if the public is considered - and senses itself - as a key stakeholder in it. Other actors close to us in the cultural heritage sector - libraries, museums, public service broadcasters - have begun to take collective action, ${ }^{19}$ and we hope that our work will advance community movement that is at least commensurate. Throughout, the White Paper also seeks to remind each of its readers that he or she (and his or her organization) is but one actor in a much larger diorama portraying, as though in a living museum, the constantly shifting relationship of men, women, information and society - shifts that take place under a raincloud, for the pessimists, or under a rainbow, for the optimists; where the public square and public space are continually defined and redefined; where access to knowledge is over and over again denied, debated, and fought over; and where the responsibilities for tying the public record to truth and reason sometimes lie in the hands of moral and Solomonic stewards, and sometimes in the hands of fools. ${ }^{20}$ Thus it is a continuously negotiated space where we do our work, but one where, on balance, freedom and justice - blind to color, blind to gender, blind to class - and maybe even equality will increasingly reign over time.

It is in this larger context, imbued with some forward-looking optimism, and for readers in a world consumed with recorded sound and the moving image, that this White Paper puts forward the following ten recommendations - delivered in the form of questions, each with a timeline - for us to use as we engage in further collective thinking and action and come together to build a new audiovisual think tank to articulate the research and action agenda for the coming decade. Not all of these recommendations will be right for every member of our group or every reader; indeed, we hope that readers draw from them all or from each as appropriate. New recommendations will be added, over time; and all are welcome - all to continue the progressive momentum that our field builds every day.

19 See, for example: https://globalvision.ifla.org/about/; https://en.unesco.org/news/step-towards-new-internationalguidelines-reproducing-heritage; and https://nem-initiative.org/future-social-media/.

20 Jürgen Habermas speaks of the ways in which we are able to directly affect, for the better, the power structure of the public sphere and deliberative politics worldwide through the production and redistribution of media. See: Habermas, The Structural Transformation of the Public Sphere: An Inquiry into a Category of Bourgeois Society, translated by Thomas Burger with the assistance of Frederick Lawrence (Cambridge: MIT University Press, 1991), and "Political Communication in Media Society," online at: http://onlinelibrary.wiley.com/doi/10.1111/j.1468-2885.2006.00280.x/full. 


\section{Recommendations}

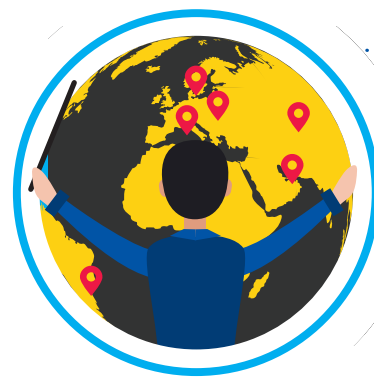

FIRST, should there be a better way for the field to know itself, its holdings, and its power? Should there be a unified catalog - a WordCat or an OCLC for the audiovisual world? A DPLA or Europeana for our common moving image and sound metadata? A European Film Gateway or EUscreen - but for the globe? Google once said, during its march to digitize them, that it had determined the world had published 129,864,880 books, identifying, in essence, the world's print archive that had at one time or another been manufactured as codexes. ${ }^{21}$ What's the equivalent tally for what's in the world's moving image and sound libraries? Although there have been some attempts at surveys - 200 million hours, UNESCO had once said - no one really knows. ${ }^{22}$ Are there solid ways of quantifying the rush of new non-television and non-film audiovisual content coming at us now - an astronomical number of moving images and sounds from billions of devices, users, and platforms? ${ }^{23}$ Beyond, perhaps, a catalog, or an inventory, or at least a

21 This was in 2010. Leonid Taycher, "Books of the world, stand up and be counted! All 129,864,880 of you," Google Books Search, August 5, 2010, online at: http://booksearch.blogspot.com/2010/08/books-of-world-stand-up-and-be-counted. html; and "Google's Tally of World's Book Titles: 129,864,880," NPR, August 12, 2010, online at: http://www.npr.org/ templates/story/story.php?storyId=129160859. The Comité des Sages of the European Commission attempted to quantify all media on the Continent to digitize in its 2011 report, The New Renaissance. See the detail in: http://europa.eu/rapid/ press-release_IP-11-17_en.htm?locale=en. The 200-page 2011 report called for an investment of 100 billion Euros to digitize all of Europe's cultural heritage - including its audiovisual collections. "The figure," noted the authors, "includes the digitisation of 77 million books, 24 million hours of audiovisual programmes, 358 million photographs, 75.43 million works of art, 10.45 billion pages of archives. ..." They added, "[A]lthough comparisons should be made with caution, investments of this type are common in other policy areas. For instance, the Research \& Development Budget for the Joint Strike Fighter programme is estimated at $€ 40.34 \mathrm{bn}$. ..." See the full report online at: http://www.eurosfaire.prd.fr/7pc/ doc/1302102400 kk7911109enc 002.pdf.

22 In 2005 UNESCO estimated world audiovisual holdings at 200 million hours. The sources for that number had always seemed somewhat unclear, and by now of course the total is completely out of date. See: Peter B. Kaufman, Assessing the Audiovisual Archive Market: Models and Approaches for Audiovisual Content Exploitation. Recently, however, one scholar pinpointed the original calculation behind that number, beginning with a 2001 Presto project that found 4.8 million hours in 10 broadcast archives. That scholar rounded the number to 5 million, and then multiplied it by 10 to form an estimate for Europe. The same scholar then doubled that total to benchmark an estimate for the entire world. Another scholar thought 100 million hours was too small and doubled it again. Such is how UNESCO published its figure! "Sic semper scientas" as the original scholar has written to me. Should individual major national archives wish to conduct some proper inventories, that would be welcome. A masterpiece of the genre is Jake Berger, ed., Guide to the BBC's Archives 2012: What's in the Archives and How to Use Them (London: BBC, 2013), online at https://en.wikipedia.org/wiki/BBC Archives (fn. 11), which should actually be here: http://www.bbc.co.uk/informationandarchives/access archives. See also the Library of Congress MIC project: https://www.loc.gov/today/cyberlc/feature wdesc.php?rec=4321. Exemplary private efforts include Rick Prelinger's The Field Guide to Sponsored Films (San Francisco: National Film Preservation Foundation, 2006), now online along with many of the cataloged films at: https://www.filmpreservation.org/sponsored-films. Additionally, it has been suggested that UNESCO and multilateral organizations like the Coordinating Council of Audiovisual Archives Associations (CCAAA) could play a role in compiling new statistics and some kind of new international inventory.

23 Richard Wright, "Television Archives in a Post-Television World," presentation at the 2017 FIAT/IFTA World Conference, Mexico City, October 21, 2017. 


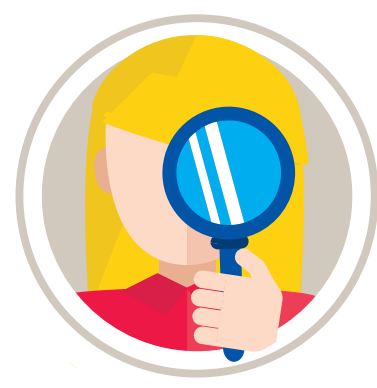

fresh effort to tote up, in general terms, the world's holdings (and propose some kind of formula that might capture the incredible rate of new production), should we make a more concerted effort through linked open data and the semantic web to create an online knowledge network of audiovisual heritage?24 Every step that archives take in truth involves both deliverables - of preservation and of access and every half of the step of access needs to focus on making the material more findable. Knowing what there is in the world would help.

Timeline: Within one year, a Working Group could help formulate an inventory of global archival holdings - and an algorithm to compute its rate of growth and define best practices from collective cultural heritage projects that make use of linked open data.

SECOND, should there be a guide to helping the machine know what we know - a guidebook of best practices written by the field for Google and other technologies to optimize audiovisual searchability and findability? YouTube playbooks are deemed highly effective by the production community; but there is not one for archives and cultural heritage organizations. An "Audiovisual Asset Playbook" could be:

a comprehensive document - and, like YouTube's, continually updated providing common-denominator information for archives large and small to optimize their content for searchability ... online. YouTube's Partner Playbook describes how best to optimize metadata, thumbnails, annotations, playlists, and channel pages, among other focal areas, and provides advisories on reaching audiences with that content, through blogs, and on social media. ... A new Audiovisual Asset Playbook could include guidelines for decision-making, annotated samples of public-private contracts that archives and their partners make available, annotated samples of revenue reports, and more..$^{25}$

Timeline: Within one year, a Task Force bringing together technologists from the public and private sectors - Google, Pandora, Amazon, Wikipedia, Netflix, Facebook, Spotify - could help describe best practices for rendering audiovisual assets more discoverable online, perhaps even including comparative analyses of metadata generation and effectiveness.

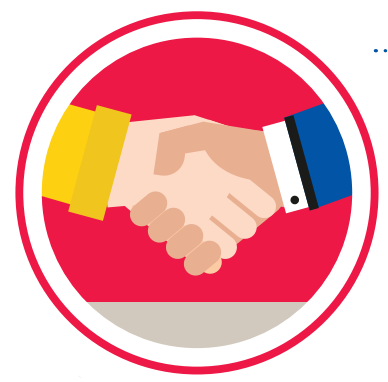

THIRD, and relatedly, for both sustainability and relevance, should there be more concerted engagement with the giants of the field like Google, Facebook, and Amazon, commercial as they are? YouTube and Facebook together controlled 77 percent of the online advertising market in the United States in 2016 - Amazon is far and away the leader in cloud storage - and ignoring them as they grow, given our own limited resources, is like ignoring

24 See, for example, Richard Wallis, Antoine Isaac, Valentine Charles, and Hugo Manguinhas, “Recommendations for the Application of Schema.org to Aggregated Cultural Heritage Metadata to Increase Relevance and Visibility to Search Engines: The Case of Europeana," code\{4\}lib 36 (April 20, 2017), online at: http://journal.code4lib.org/articles/12330. 


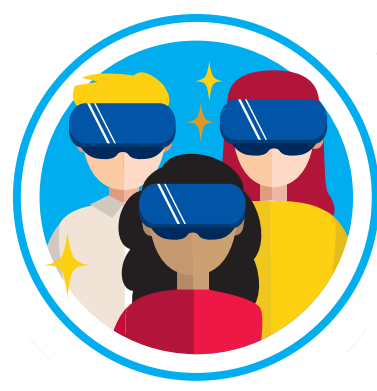

water, air, and earth. ${ }^{26}$ Should we put forward some ideas and theses of our own - rules of the game, codes of conduct - experienced as many of us are with public-private partnerships, for dealing with these behemoths? What should the relationship be between noncommercial organizations - and the educational and cultural sector in particular - and these online giants, especially those with whom many of us work to publish, promote, and preserve information? ${ }^{27}$

Timeline: Within one year, a cultural heritage leaders group - perhaps also spanning libraries, museums, public media - could outline some basic principles for engagement with private sector partners as vendors and partners and more.

FOURTH, especially as we watch the private sector grow, what should be our own commitment to constant experimentation? As the impact of machine learning grows; as machines also make progress to take over curation, transcription, and annotation; as third parties may take over storage - what will be the differentiating factors of cultural and educational media archives and full-time archive professionals? ${ }^{28}$ Perhaps the future archivist plays a role as media manager, managing assets from their inception all the way through to distribution and long-term storage. How do we encourage the field to continue exploring - with "living laboratories"29 and new models of audiovisual "studios," where shared spaces promote collaborative teaching and learning? ${ }^{30}$ And how do we balance some of the more exciting areas of exploration - data analytics, tracking content, putting digital collections at scale into the hands of

26 Rolfe Winkler and Laura Stevens, “Tech Giants Alphabet and Amazon Extend Earnings Boom, The Wall Street Journal, April 27, 2017, online at: https://www.wsj.com/articles/tech-giants-alphabet-and-amazon-extend-earnings-boom-1493337777; and Ron Miller, “AWS Still Owns the Cloud," TechCrunch, February 27, 2017, online at: https://techcrunch.com/2017/02/02/awsstill-owns-the-cloud/. In a nutshell, “Google controls more than 90 per cent of search-engine traffic in Europe, and 88 per cent in America; YouTube, also owned by Alphabet, is the largest music-streaming site in the world; Amazon takes more than half of every new US dollar spent online; Facebook, having swallowed competition like Instagram and WhatsApp, holds 77 per cent of all mobile social media traffic, and recently reached 2 billion members. With Apple and Microsoft, these are now the five largest companies in the world . . . with a collective net worth of $\$ 3$ trillion." And: "Together they spend more on government lobbying than the five biggest banks or the five largest oil companies." Samuel Earle, "Vatican 2.0," Times Literary Supplement, November 17, 2017, online at: https://www.the-tls.co.uk/articles/public/technology-companies-facebook-god-earle/.

27 Peter B. Kaufman and Jeff Ubois, “Good Terms: Improving Commercial-Noncommercial Partnerships for Mass Digitization," D-Lib Magazine 13, no. 11/12 (November/December 2007), online at: http://www.dlib.org/dlib/november07/ kaufman/11kaufman.html.

28 Johan Oomen, "Audiovisual Archives, The Next Ten Years: Turning Vision into Reality and Positive Change," Medium, October 18, 2015, online at: https://medium.com/@johanoomen/soima-turing-vision-into-reality-and-positive-changefc2388ea953f; and Farhad Manjoo, "Can Facebook Fix Its Own Worst Bug?" The New York Times, April 25, 2017, online at: https://www.nytimes.com/2017/04/25/magazine/can-facebook-fix-its-own-worst-bug.html.

29 For example, see: http://labs. beeldengeluid.nl/.

30 See John Seeley Brown's discussion of ateliers and productive inquiry in "New Learning Environments for the $21^{\text {st }}$ Century," online at: http://www.johnseelybrown.com/newlearning.pdf. 


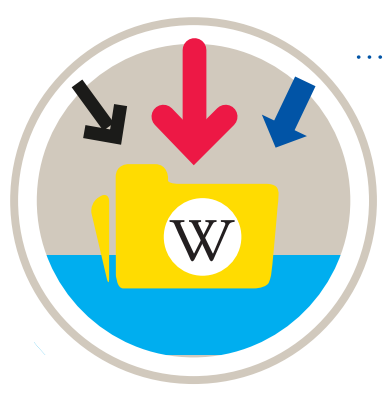

researchers, and all the attendant benefits for machine learning - with our innate responsibility to object to deeper surveillance and protect user privacy on the web? Among the most interesting opportunities, one could be deploying "cognitive technologies" - IBM Watson Media, for example ${ }^{31}$ - into our future work.

Timeline: Within one year, a Working Group could complete a survey of experimentation within audiovisual archives, featuring especially novel approaches to curation such as several of those under way at EUscreen. ${ }^{32}$

FIFTH, should we launch a real effort to engage with Wikipedia? Now may be the moment to bring Wikipedians in residence, to hold edit-a-thons, to become Wikipedians, to develop strategies for distributing our material across the Commons and getting the Commons to shine its lights back on our work. ${ }^{33}$ How do archives connect with human knowledge, and what role do archivists have to nourish those connections? This is part of a larger discussion of the relationship between human beings and machines in the digital age - and the proper roles of professional and also dedicated amateur curators, including even pirates and those involved in illegal forms of distribution, in contextualizing facts and truths and publishing knowledge and distributing information. ${ }^{34}$

Timeline: Beginning immediately, and stretching over five or ten years, archivists could welcome in Wikipedia experts for edit-a-thons, hack days, as "Wikipedia Fellows," ${ }^{35}$ and more, all to promote the use of their audiovisual material in the grand Wikimedia commons.

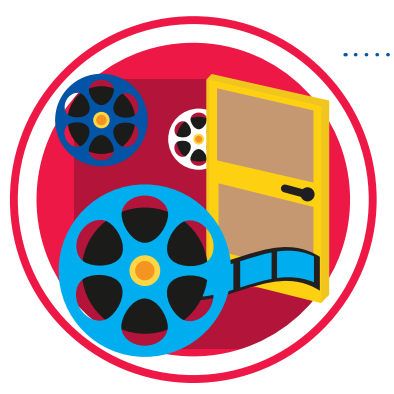

SIXTH, should it be put forward somewhere that the work of FIAT/IFTA and PrestoCentre and individual archives like Sound and Vision should always be centered on pushing information to be unfettered and free? The growth of the Commons and online sharing has reached a tipping point. Wikipedia and its sister projects have seen almost 3 billion edits now; the online encyclopedia clocks more than 350 edits per minute $-20,000$ articles per month,

31 See: https://www.ibm.com/watson/media/.

32 See, for example, the video posters tab on http://euscreen.eu/.

33 Peter B. Kaufman, "In the Post-Truth Era, Colleges Must Share Their Knowledge," Chronicle of Higher Education, April 2, 2017, online at: http://www.chronicle.com/article/In-the-Post-Truth-Era/239628. See also the work of many active in the "video and the commons" effort: https://benrito.github.io/video-commons2017/ and http://benrito.github.io/videocommons2016\%.

34 Understanding the roles that pirate activity and pirate networks play with our content is also essential. iTunes, it has been said, would never have emerged without Napster. See: Darren Waters, "Napster: 10 Years of Change," BBC News, June 8, 2009, online at: http://news.bbc.co.uk/2/hi/technology/8089221.stm.

35 For example: https://wikiedu.org/blog/2017/11/14/announcing-wikipedia-fellows/. The television show Family Guy has a much more replete set of online encyclopedia articles than the BBC's Storyville or PBS's Frontline. Perhaps that could change.... 
worldwide. ${ }^{36}$ Creative Commons now has more than 1 billion licenses in circulation. CClicensed works were viewed online more than 100 billion times in 2015 alone, and growth in the use of CC-licensed content, while challenging to track, appears to be commensurate. ${ }^{37}$ And increasingly, the funders of our work will mandate open/free access provisions as a condition for receiving their support. ${ }^{38}$ Does the community have a responsibility to engage with free and liberal licenses, and free and open standards, for its content, its software, its work product? What access should we be guaranteeing to the disabled and disadvantaged? ${ }^{39}$ And more broadly, for the materials we curate, do we consider facilitating present access to past culture as some kind of professional obligation $?^{40}$ What rights do we believe people have to explore and interrogate and cite and use - and own - their own creative heritage? Does it really make sense that, by some laws, we should have to license permission to work with songs like ... "We Shall Overcome"? ${ }^{41}$ How can we best draw inspiration from archival victories, such as the new American Archive's achievements in posting celebrated civil rights documentaries and their component parts $?^{42}$ Are there ways of more systematically interrogating what types of legal and other risks our digitization and publication projects actually entail?

Timeline: Within one year, FIAT/IFTA and other bodies could consider issuance of a statement of principle or two in this area, and perhaps assemble an additional focused Working Group on free licenses for content assets and code.

36 "FPC Briefing: Wikipedia - Reliable Sources, Open Sources, and Knowledge", filmed April 11, 2017, Washington, DC, U.S. Department of State, video, 46:29, https://video.state.gov/detail/videos/category/video/5393904847001/?autoStart=true.

37 See: http://pro.europeana.eu/blogpost/the-yellow-milkmaid-syndrome-paintings-with-identity-problems; http:// custodians.online/; https://stateof.creativecommons.org/; https://stateof.creativecommons.org/data-andacknowledgements-page/; https://creativecommons.org/weblog/entry/46712/; https://en.wikipedia.org/wiki/ Wikipedia:Statistics; https://en.wikipedia.org/wiki/Wikipedia:About; and https://en.wikipedia.org/wiki/Special:Statistics.

38 See the essential work of the Smithsonian's Effie Kapsalis, "The Impact of Open Access on Galleries, Libraries, Museums, and Archives," April 27, 2016, online at: https://siarchives.si.edu/sites/default/files/pdfs/2016_03_10_OpenCollections Public.pdf; the published requirements of the European Commission, March 21, 2017, online at: http://ec.europa.eu/ research/participants/data/ref/h2020/grants_manual/hi/oa_pilot/h2020-hi-oa-pilot-guide_en.pdf; and the new Open Research Funders Group in the United States, online at: http://www.orfg.org/news/.

39 See, for one statement: https://www.ebu.ch/news/2017/02/broadcasters-and-disability-organisation-draw-up-commonrecommendation-on-future-eu-rules-for-audiovisual-access-services.

40 See the work of Communia/The European Thematic Network on the Digital Public Domain," online at: http://communiaproject.eu/final-report/.

41 Edward Helmore, “Civil Rights Anthem We Shall Overcome Freed from Copyright," The Guardian, September 12, 2017, online at: https://www.theguardian.com/music/2017/sep/11/we-shall-overcome-civil-rights-anthem-copyright-lawsuit.

42 Ryn Marchese, "American Archive of Public Broadcasting Releases Exclusive Collections," American Archive of Public Broadcasting, November 7, 2017, online at: https://americanarchivepb.wordpress.com/2017/11/07/american-archive-ofpublic-broadcasting-releases-exclusive-collections/. 


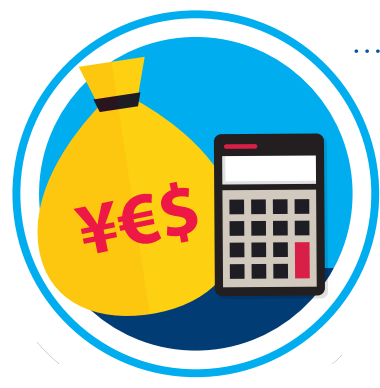

SEVENTH, and more directly toward sustainability, if digital content - even with the outstanding efforts of establishments like INA and BnF's publishing department ${ }^{43}$ - is increasingly harder to license, rent, and sell online, and every new effort at digital rights management, so we are told, will be broken, ${ }^{44}$ then advertising will become the primary means of generating revenue against archival moving image content in the future. How should we consider this advertising business - from a business perspective? Should we imagine collaborating over establishing a kind of advertising agency to represent ourselves and sell time on our content to seaworthy companies with whose brands it would be not unpleasant to associate - in short, to engage them as potential partners and as equals? ${ }^{45}$ We may need to measure the impact of our work in ways similar to how advertisers measure impressions. Indeed, efforts in this direction have already begun - with Europeana's new Impact Playbook, for example, presenting new and creative metrics for social impact, economic impact, innovation impact, and operational impact. ${ }^{46}$

Timeline: Over the next three years, the field could begin and then deepen discussion with agencies and select advertisers to explore this underinvestigated revenue model and new models for measuring the societal impact so vital to the field.

43 "L'Institut national de l'audiovisuel: Free Content and Rights Licensing as Complementary Strategies" (London: JISC, 2011), online at: http://www.sr.ithaka.org/wp-content/uploads/2015/08/SCA_BMS_CaseStudy_INA.pdf.

44 Cory Doctorow, "How We Will Kill All the DRM in the World in a Decade," https://www.fsf.org/news/libreplanet-2017keynote-announcement-author-and-tech-activist-cory-doctorow; http://boingboing.net/2016/08/17/podcast-how-well-killall-t.html; and https://www.eff.org/press/releases/cory-doctorow-rejoins-eff-eradicate-drm-everywhere.

45 Peter B. Kaufman, On Building a New Market for Culture: Virtue and Necessity in a Screen-Based Culture (London: JISC, 2009), online at: https://sca.jiscinvolve.org/wp/files/2009/07/sca_intelligenttv_sponsorship report v1-final.pdf.

46 Harry Verwayen, "The Impact of Cultural Heritage: Creating a Common Language," Medium, March 14, 2017, online at: https://medium.com/@Hverwayen/the-impact-of-cultural-heritage-creating-a-common-language-28cba0e1afob; https:// pro.europeana.eu/page/impact-resources; and http://pro.europeana.eu/blogpost/business-plan-2017-spreading-theword. Getting metrics right is a challenge - even billion-dollar enterprises have trouble. Mike Shields, "Facebook Says It Found More Miscalculated Metrics," The Wall Street Journal, November 16, 2016, online at: https://www.wsj.com/articles/ facebook-says-it-found-more-miscalculated-metrics-1479303984; Todd Spangler, "Facebook Discloses Yet Another Ad Measurement Glitch, Will Refund Affected Clients," Variety, May 16, 2017, http://variety.com/2017/digital/news/facebookadvertising-measurement-error-refunds-1202429254/; and Matthew Ingram, "Facebook's Latest Ad Measurement Error Comes at the Worst Possible Time," Fortune, May 17, 2017, online at: http://fortune.com/2017/05/17/facebookmeasurement-error/. 


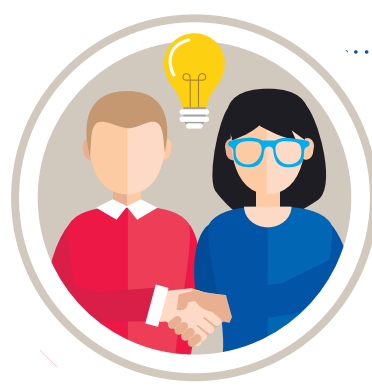

EIGHTH, should archivists liaise more fluidly with producers and creators? Each has much to learn from the other. Everything that an archive publishes is in effect a new production. And everything produced is eventually an archivable thing. Film and television preservationists are also now publishers and distributors. While it's true that in pre-digital days this may have been an operative statement, all of us occupy places along the great knowledge assembly line and we shift spots from time to time. Archivists are producers of new content - they are often de facto distributors of this new content by virtue of the existence of the Internet alone. Distribution has been a vexing problem for a century. ${ }^{47}$ And in the space of that century, the media involved have changed shape fast and furiously. ${ }^{48}$ Applying archival principles to production is as important as applying production principles to archiving. ${ }^{49}$ At the 2017 FIAT/ IFTA World Conference, more than one participant noted the preponderance of award-winning recent feature films and television productions - I Am Not Your Negro, O.J.: Made in America, The Beatles: Eight Days a Week, $13^{\text {th }}$, The Black Panthers: Vanguard of the Revolution - meeting with both critical acclaim and box-office success..$^{50}$ As production projects that feature archives proliferate, and as new works get co-produced by producers, directors, and archives, our dialogue with producers and consumers about creative use and reuse - and rights - may take a turn for the better.

Timeline: Over the next five years, establish more meetings and exchange programs between archivists and producers! Embed archivists, seasoned and junior, in our major television and moving image productions - and, especially in light of these recent successes, give to brave documentarians, news producers, and artists and creators a pass to wander through our archives for good, long (and productive!) stretches of time. ${ }^{51}$

47 Richard Abel, “The 'Much Vexed Problem' of Nontheatrical Distribution in the Late 1910s," The Moving Image 16, no. 2 (Fall 2016).

48 Books are different. "The printer Daniel Bomberg's first full edition of the Talmud, produced in 1523, boasted a layout original Talmudic text in the center, selected commentaries in the margins - that has remained unchanged for almost five centuries." See: Harry Freedman: The Talmud: A Biography (New York: Bloomsbury, 2014), reviewed in Wall Street Journal, November 3, 2014, online at: https://www.wsj.com/articles/book-review-the-talmud-a-biography-by-harryfreedman-1414972212.

49 For example, http://www.themindoftheuniverse.org/; Melody Kramer and Anu Paul, "Opening Access to Fresh Air's Archives," Provenance: Journal of the Society of Georgia Archivists 34, no. 1 (2016), http://digitalcommons.kennesaw.edu/ provenance/vol34/iss1/6; and Dallas C., Hanbury, "Build It and Will They Come? Participatory Digital Archives, Hesitant Users, and the Emerging Archival Commons," Provenance: Journal of the Society of Georgia Archivists 32, no. 1 (2014), http://digitalcommons.kennesaw.edu/provenance/vol32/iss1/6.

50 Matthew White, "The Shock of the Old: Excavating Analog Film and Video Archives for Premium Documentaries," presentation at the 2017 FIAT/IFTA World Conference, Mexico City, October 19, 2017.

51 See, for example, the work of filmmaker/storyteller Adam Curtis in the BBC Archive, online at: http://www.bbc.co.uk/ blogs/adamcurtis. 


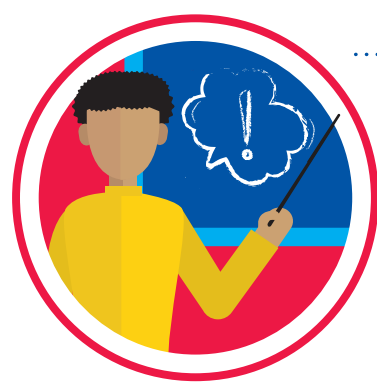

NINTH, to return to the Enlightenment and concerning our job as educators, how do we define our roles as educators today, especially as so many young people see and hear the world through moving images and sounds that we may one day be called upon to safekeep? Should we draw up a statement of principles committing/recommitting ourselves to the task - which again is now more important than ever? What responsibility do we have to educate - as part of our daily professional lives? And how can we best encourage educators, as they move into the moving image medium, in turn to archive the important work that they produce - and to show others how to use those archives as much as they have been demonstrating to students so very fluently for centuries how to use the best libraries? How do we help to provide our resources to the humanities and social sciences, the hard sciences, every professional discipline - and enable others to use those resources to educate and train?

Timeline: Within two years, a visionary could be called upon to present the equivalent of the vision articulated over a decade ago for the great global meta-university - in short, for the great global meta-archive. ${ }^{52}$

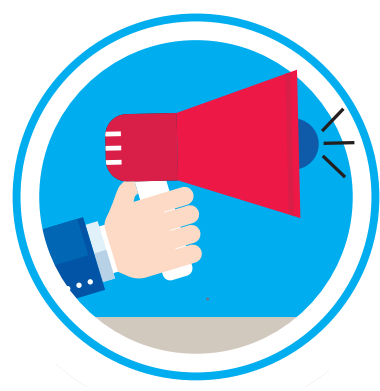

TENTH, what role, if any, should archives play in the political/media/cultural arena? We'd recommend an active role with complex issues at the forefront of digitization such as copyright reform and campaigns for access to knowledge. It might also be worthwhile for archives to join in, more directly, when broadcasters establish, in this new age, fact-checking units to examine and correct the distribution of falsehood online. ${ }^{53}$ Indeed, we would say that freedom of speech issues in every country and before every body - national and international - also require constant vigilance, and in these battles, archivists should never hesitate to play partisan in the struggle for rights

52 MIT President Charles Vest spoke of "a transcendent, accessible, empowering, dynamic, communally constructed framework of open materials and platforms on which much of higher education worldwide can be constructed or enhanced. ... [T]he meta-university will enable, not replace, residential campuses, especially in wealthier regions. It will bring cost-efficiencies to institutions through the shared development of educational materials. It will be adaptive, not prescriptive. It will serve teachers and learners in both structured and informal contexts. It will speed the propagation of high-quality education and scholarship. It will build bridges across cultures and political boundaries. It will be particularly important to the developing world." Charles Vest, "Open Content and the Emerging Global Meta-University," EDUCAUSE Review 41, no. 3 (May/June 2006): 18-30, online at: http://er.educause.edu/articles/2006/1/open-content-and-theemerging-global-metauniversity. See also: Kurzweil, The Singularity is Near; http://singularity.com/; and Kurzweil's vision of a university for the future, online at: https://www.ted.com/talks/ray kurzweil announces singularity university.

53 The BBC's "Permanent Reality Check" team comes to mind, with the BBC News Chief having said, "The BBC can't edit the internet, but we won't stand aside either." Jasper Jackson, "BBC Sets Up Team to Debunk Fake News," The Guardian, January 12, 2017, online at: https://www.theguardian.com/media/2017/jan/12/bbc-sets-up-team-to-debunk-fake-news. Such is the spirit behind the new audiovisual "truth-tracker" consortium's project, online here: http://www.invid-project. eu/. See also: https://inkdroid.org/2017/11/13/prospectus/. 
and freedom. ${ }^{54}$ Even more, audiovisual archivists need to be using the skills and assets at their disposal to counter the baboons and mountebanks who sometimes ascend to the thrones of power in our countries. It is no accident that the etymology of the word 'archive' comes from the Greek áp $p \omega$ - to begin, rule, govern - and thus no accident that "archive" shares the same root as the word for monarch or hierarchy..$^{55}$ Archives started in the "archon" - the seat of government - and the centrality of the power of the archive is likely to be the story of the $21^{\text {st }}$ century. ${ }^{56}$

Timeline: Start this one tomorrow morning.

54 We live only once, and we might as well use the voice we've each been granted. See, for example, the United Nations "2030 Agenda for Sustainable Development," Article 25: “All people, irrespective of sex, age, race, ethnicity, and persons with disabilities, migrants, indigenous peoples, children and youth, especially those in vulnerable situations, should have access to lifelong learning opportunities that help them acquire the knowledge and skills needed to exploit opportunities and to participate fully in society. Goal 9. Build resilient infrastructure, promote inclusive and sustainable industrialization and foster innovation: 9.5 Enhance scientific research, upgrade the technological capabilities of industrial sectors in all countries, in particular developing countries, including, by 2030, encouraging innovation and substantially increasing the number of research and development workers per $1 \mathrm{mi} ., "$ online at: https://sustainabledevelopment.un.org/post2015/ transformingourworld.

55 See: https://en.wikipedia.org/wiki/Archon.

56 The battles over that history have already begun. See Peter B. Kaufman and Jeff Ubois, "The Devolution Will Be Televised," The Nation, October 18, 2017, online at: https://www.thenation.com/article/the-devolution-will-be-televised/. 


\section{Conclusions}

This White Paper addresses the contemporary context for our work and many of the various challenges we face, and it has assembled many recommendations, clustering them for the purpose of launching discussion around these ten poles:

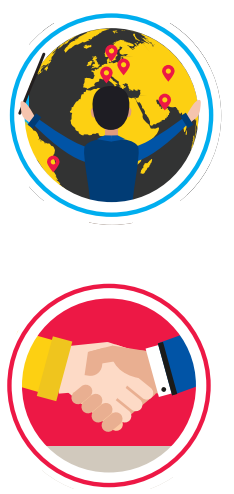

RECOMMENDATION 1

Conduct a global

inventory of archival

holdings.

RECOMMENDATION 3

Explore relationships

with the private sector.

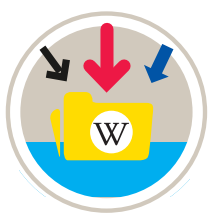

RECOMMENDATION 5 Engage more fully with Wikipedia.

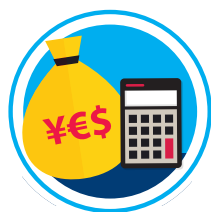

\section{RECOMMENDATION 7}

Explore future revenue models.

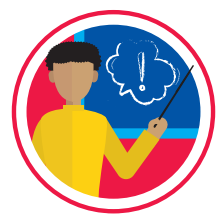

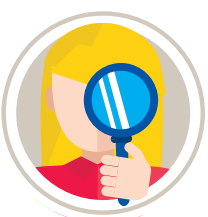

RECOMMENDATION 2

Focus on discoverability.

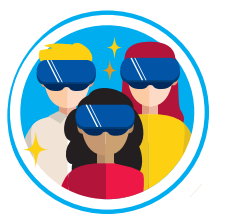

\section{RECOMMENDATION 4}

Experiment - with technology, media - constantly within AV archives.

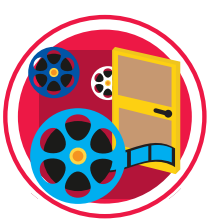

\section{RECOMMENDATION 6}

Deploy free and liberal licenses and free and open standards.

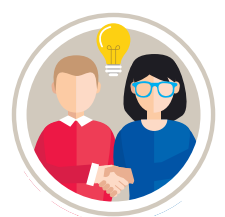

\section{RECOMMENDATION 8}

Engage archivists to work more closely with producers and creators.

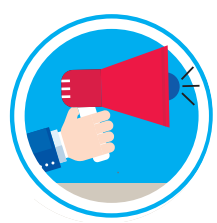

\section{RECOMMENDATION 10}

Engage archives with issues in the media/political/cultural arena.

Should we double the number of recommendations here - 10 in all - that we might follow, or cut their number in half, the better to focus? Each of us in our chosen professions - in education, in culture - needs to take a moment, a deep breath, and transcend the picayune. We need to remember to see the whole forest as well as the trees - and look for what unites us rather than what might separate us as people. This is the way ahead. We work at a time when there seems to be a global effort to plow and seed the world full of avarice, lies, and everything foul and toxic. So this is not a time for baby steps. It will be more useful to be bold and progressive. The choice is ours. For all involved, including those who will help to survey best practices in the field and establish this new Think Tank, it's a path best traversed collectively, in a fresh, new, open, and participatory exploration. And as we go on along in that way, every step of the way, archivists should remember their individual strengths - and their collective power when they work together. 
